\title{
USE OF A 2-INCH, DUAL SCREEN WELL TO CONDUCT AQUIFER TESTS IN THE UPPER AND LOWER LOST LAKE AQUIFER ZONES: WESTERN SECTOR, A/M AREA, SRS
}

R. A. Hiergesell

J. S. Novick

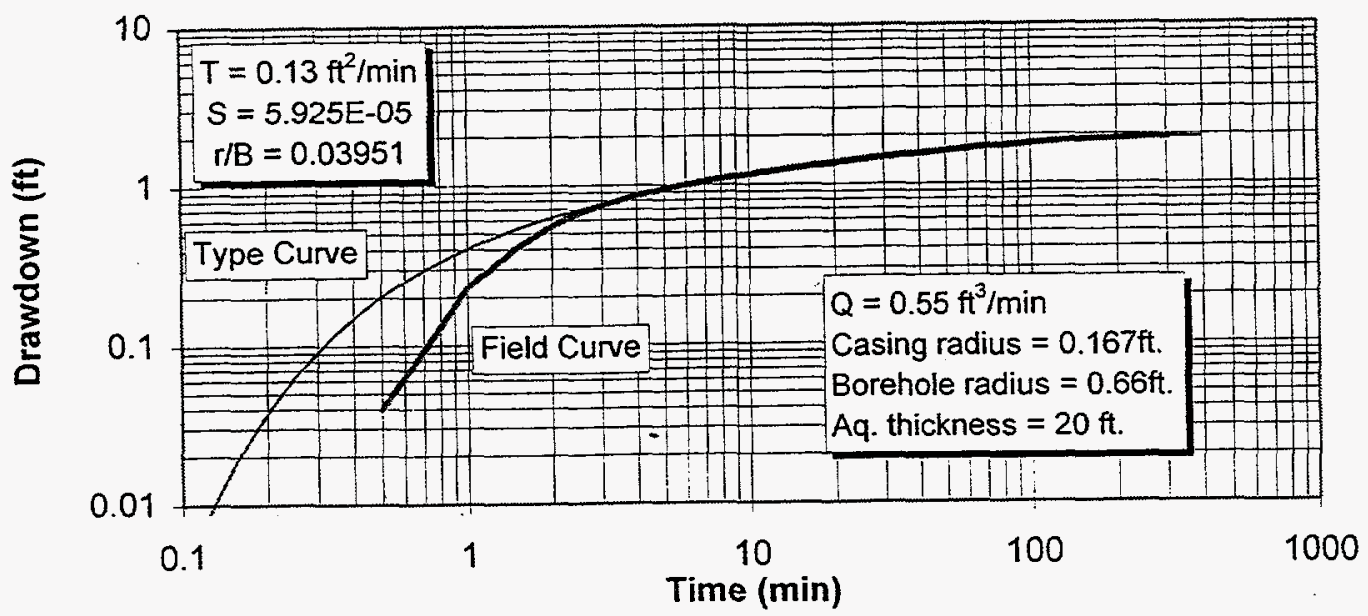

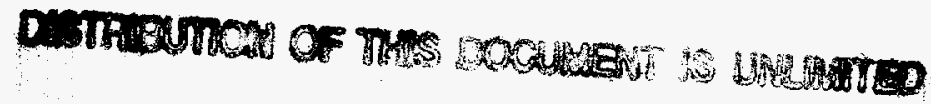

Westinghouse Savannah River Company

Savannah River Site

Aiken, SC 29808

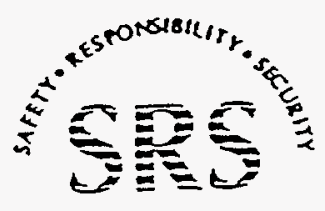

Prepared for the U. S. Department of Energy under Contract No. DE-AC09-89SR18035 


\section{DISCLAMIER}

Portions of this document may be illegible in electronic image products. Images are produced from the best available original document. 


\section{DISCLAIMER}

This report was prepared as an account of work sponsored by an agency of the United States Government. Neither the United States Government nor any agency thereof, nor any of their employees, make any warranty, express or implied, or assumes any legal liability or responsibility for the accuracy, completeness, or usefulness of any information, apparatus, product, or process disclosed, or represents that its use would not infringe privately owned rights. Reference herein to any specific commercial product, process, or service by trade name, trademark, manufacturer, or otherwise does not necessarily constitute or imply its endorsement, recommendation, or favoring by the United States Government or any agency thereof. The views and opinions of authors expressed herein do not necessarily state or reflect those of the United States Government or any agency thereof. 


\section{TABLE OF CONTENTS}

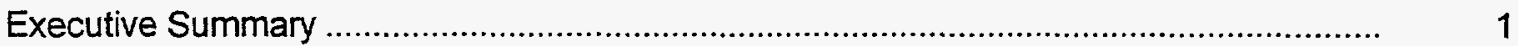

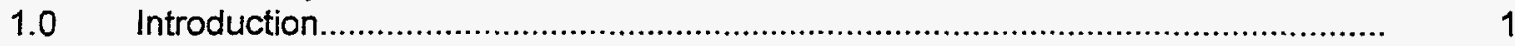

$1.1 \quad$ Objective and Purpose .............................................................................

$2.0 \quad$ Hydrogeologic setting ....................................................................................

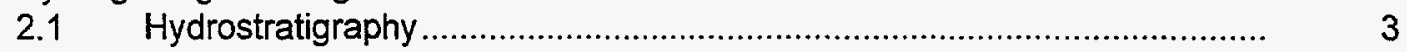

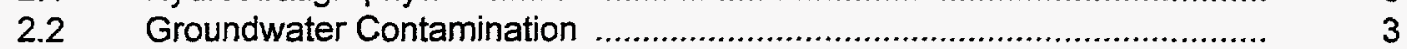

3.0 Well Installation and Construction Design .......................................................... 8

4.0 Instrumentation and Test Design ......................................................................

4.1 Site Instrumentation.............................................................................

4.2 Test Design...............................................................................

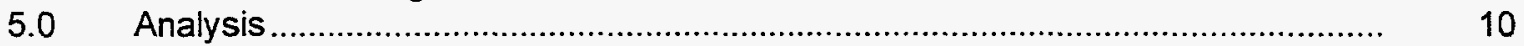

5.1 Drawdown response............................................................................ 10

$5.2 \quad$ Groundwater chemistry........................................................................ 10

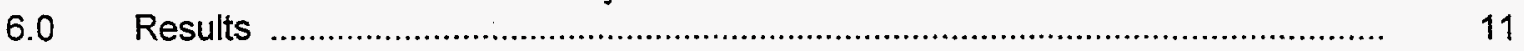

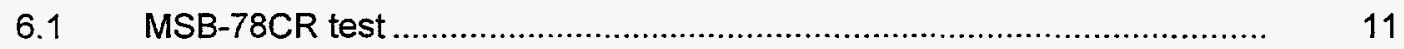

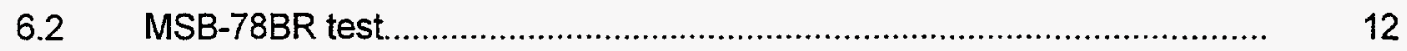

6.3 Confining unit vertical hydraulic conductivity ................................................. 14

6.4 Chemical analyses of groundwater samples................................................ 15

7.0 Conclusions .................................................................................................... 16

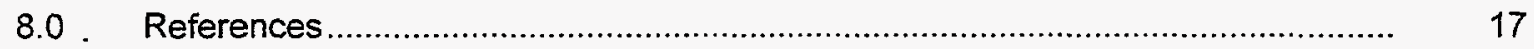

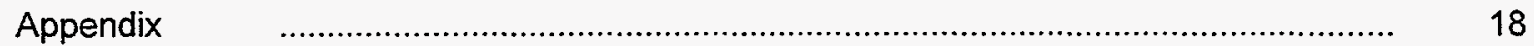

\section{LIST OF FIGURES}

Figure 1 Location of MSB-78 Well Cluster in the Western Sector, AMM Area .............. 2

Figure 2 Potentiometric Surface for the Upper Lost Lake Aquifer .............................. 4

Figure 3 Potentiometric Surface for the Lower Lost Lake Aquifer ............................... 5

Figure 4 Hydrostratigraphic Cross-Section near MSB-78B/C...................................... 6

Figure 5 MSB-78CR Hydrograph ............................................................. 11

Figure $6 \quad$ MSB-78CR Match of Field Data with Hantush Analytical Curve..................... 12

Figure 7 MSB-78BR Hydrograph ....................................................................... 13

Figure $8 \quad$ MSB-78BR Match of Field Data with Hantush Analytical Curve.................... 13

\section{LIST OF TABLES}

Table 1 Summary of hydraulic characteristics for both aquifer tests

Table 2 Comparison of hydraulic parameters from this investigation with other estimates from the Upper and Lower Lost Lake Aquifer in the AMM Area...... 


\section{EXECUTIVE SUMMARY}

Two aquifer tests were conducted at MSB-78B/C, located in the Western Sector of the AMM Area. $\mathrm{MSB}-78 \mathrm{~B} / \mathrm{C}$ is a 2-inch diameter well having two separate screen zones, each finished in the Upper and Lower Lost Lake Aquifer Zones, respectively. Each screen zone was pumped separately using an inflatable packer to isolate one zone from the other during the tests. Hydraulic responses to pumping during each test were monitored in separate wells located 25 feet from the pumping well. The hydraulic parameters Transmissivity, Storativity, and Leakance were calculated for the Upper and Lower Lost Lake Aquifer Zones using the drawdown responses. Pumping rates of 4.1 gallons per minute were achieved during each test and all purged water was collected in a tanker truck and transported to an air stripper for disposal.

\section{$1.0 \quad$ INTRODUCTION}

The Western Sector, A/M Area is located just west of the M-Area Settling Basin on an upland area. The area is adjacent to the gently inclined area where the upland drops off to the Savannah River floodplain. Water in the parts of the uppermost aquifers contains dissolved contaminants which originated at the land surface and have leached downward into the groundwater. Subsurface contamination originated in the locality of the M-Area Settling Basin and Lost Lake, which is a Carolina Bay. These locations functioned as disposal sites for industrial solvents during the early years of operation of the Savannah River Site. The primary groundwater contaminants are trichloroethylene (TCE) and tetrachloroethylene (PCE), and groundwater concentrations of TCE are significantly greater than the PCE.

Within the A/M Area a program was initiated in the early 1980's to remediate the subsurface contamination. Pump and treat technology has been applied to groundwater in the shallowest aquifers and vapor extraction in the vadose zone has been applied to intercept contaminants before they reaches the saturated zone. Remediation efforts in the A/M Area have utilized groundwater flow models to guide the location of extraction wells. Groundwater flow models require input data which is based on characterization efforts of the groundwater flow system. One type of information required is the hydraulic characteristics of the aquifer and aquitard units in the groundwater flow system.

The activities described in this report relate to the instrumentation of a field site at the MSB-78 well cluster location for conducting two aquifer tests, conducting the two tests, and the analysis of water level drawdown responses to calculate hydraulic parameters for the Upper and Lower Lost Lake Aquifer Zones. The location of the MSB-78 well cluster in the Western Sector is shown on Figure 1. During the aquifer tests water samples were collected so that concentrations of TCE and PCE could be determined.

\subsection{Objective and purpose}

The primary objective of this investigation was to obtain estimates of hydraulic parameters for the Upper and Lower Lost Lake Aquifers in the Western Sector of the AMM Area. The hydraulic parameters calculated in this analysis include the horizontal hydraulic conductivity, storativity, and leakage coefficient for the two aquifer zones and the confining zone vertical hydraulic conductivity. The purpose of obtaining these parameter values is to improve conceptual understanding of groundwater flow system in Western Sector of AM Area, and to provide data that will be used to improve the calibration of the existing groundwater flow models of the A/M Area groundwater flow model, which will be utilized in assessing the effectiveness of groundwater remediation activities in the Western Sector. A secondary purpose was to demonstrate the feasibility of using a dualscreen, 2-inch diameter, well for conducting multiple-well aquifer tests in and area of suspected groundwater contamination. 


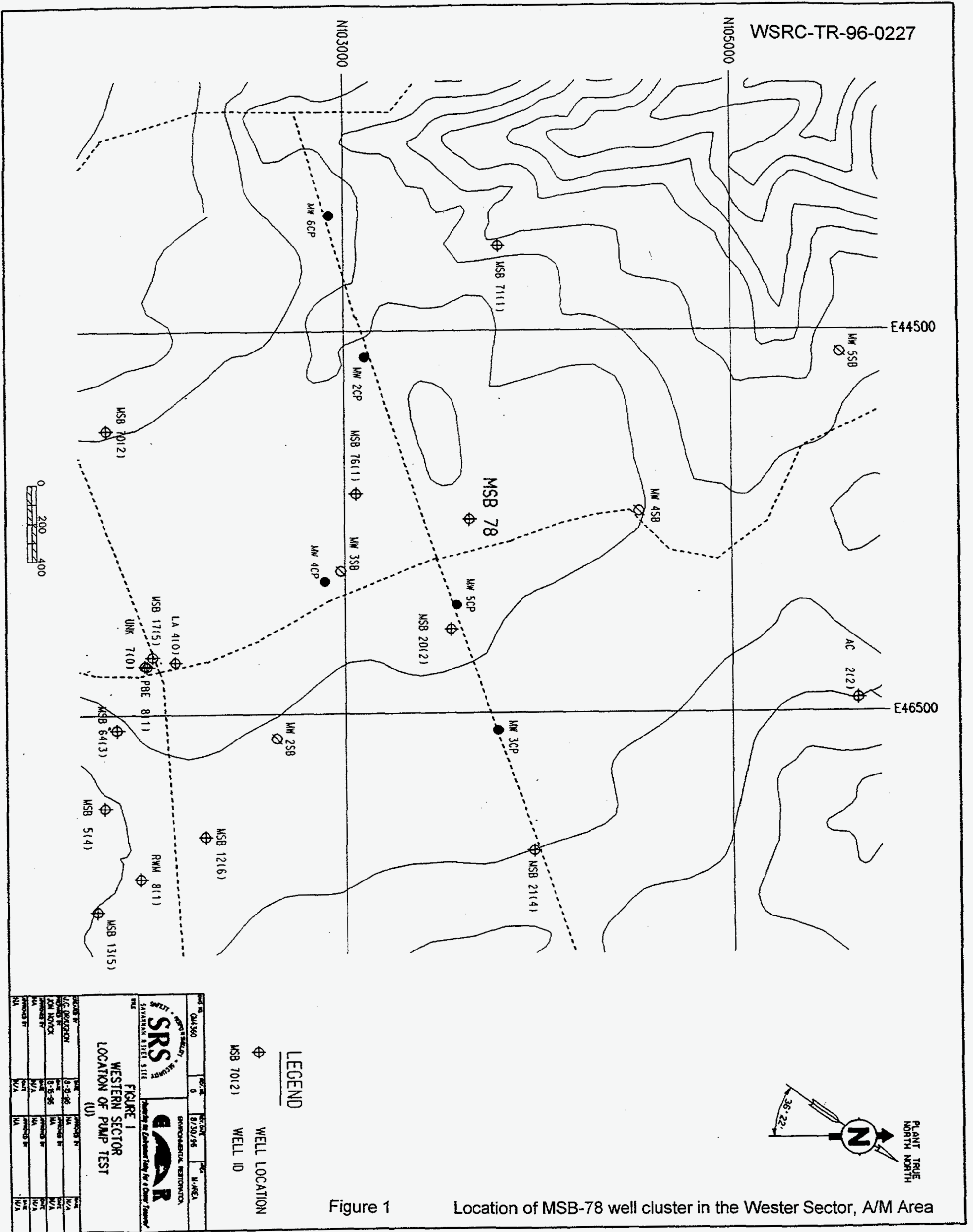




\subsection{HYDROGEOLOGIC SETTING}

\subsection{Hydrostratigraphic Setting}

Typical of the Atlantic Coastal Plain, the sediments beneath AM Area are interbedded sands, silts, and clays. Clay rich confining, or restrictive, intervals are interspersed with more transmissive, sandier intervals. The general pattern of subsurface water flow and sequence of water bearing zones in the A/M Area is discussed below.

The uppermost hydrostratigraphic units, in descending order, include the Water Table, or M-Area Aquifer Zone, the Green Clay Confining Unit, the Lost Lake Aquifer Zone, and the Crouch Branch Confining Unit. The Green Clay Confining Zone is a leaky aquitard which acts to impede water flow from the M-Area Aquifer Zone to the Lost Lake Aquifer Zone. An unnamed, and somewhat discontinuous, aquitard divides the Lost Lake Aquifer Zone into upper and lower sub-zones in parts of the A/M Area. Although discontinuous, this aquitard is usually very competent in restricting vertical movement of groundwater where it is present. Underlying the Lost Lake Aquifer Zone is the Crouch Branch Confining Unit which consists of an upper aquitard, a middle sand, and a more effective lower aquitard. This confining unit appears relatively effective in minimizing downward flow from the Lost Lake Aquifer Zone into the underlying Crouch Branch Aquifer throughout most of the AVM Area. A more detailed compilation of information on the hydrostratigraphy of the AMM Area is presented Aadland, et. al., (1995), however there are some differences in nomenclature between this report and Aadland, et. al. (1995). In this report the Upper Lost Lake Aquifer Zone is identified separately from the Lower Lost Lake Aquifer Zone because of the presence of the clay zone ( 15 feet thick) located near the middle of the Lost Lake Aquifer in the vicinity of the MSB-78 well cluster. Due to the intermittent presence of this confining unit, Aadland et. al. has referred to the Lost Lake Aquifer without identifying sub-zones.

In the Western Sector of the AMM Area, horizontal movement of groundwater within the M-Area Aquifer Zone and the Lost Lake Aquifer Zone is predominantly westward, toward the Savannah River. The Savannah River is a regional groundwater discharge zone and even the deepest aquifers in the area discharge to it. The water table decreases in elevation from the A/M Area in the direction of the Savannah River and eventually it drops below the Green Clay Confining Unit into the Lost Lake Aquifer Zone between MSB-78 and the Savannah River floodplain. There is a downward hydraulic gradient in the shallow aquifers near the MSB-78 well cluster and, consequently, there is some vertical groundwater movement in the downward direction in the uppermost aquifer and aquitard units near the MSB-78 well cluster site. Vertical movement is more pronounced in places where confining units are thin or absent. Within the Upper and Lower Lost Lake Aquifer Zones, the predominant horizontal direction of flow is to the southwest. The configuration of the potentiometric surfaces for each of these zones is illustrated in Figures 2 and 3. Potentiometric contours were developed after posting water level measurements obtained from other wells in the vicinity of the MSB-78 well cluster. A hydrogeologic cross-section illustrating the position of the well screens in MSB-78B/C relative to the units is shown in Figure 4.

\subsection{Groundwater Contamination}

Operations at the SRS, AVM Area have resulted in the release of chlorinated solvents to the subsurface. The solvents are primarily trichloroethylene (TCE) and tetrachloroethylene (PCE), both of which are immiscible with water and are soluble in groundwater in only trace concentrations (Looney, 1992). The solvents also tend to form a dense, non-aqueous phase that migrates downward through the vadose zone near the source areas and continues through the saturated zone. The primary source area of TCE contamination is in the vicinity of the M-Area Seepage Basin and Lost Lake. These facilities are located approximately 2500 feet east of the MSB-78 well cluster. A large plume of TCE and PCE is dissolved in the groundwater beneath 


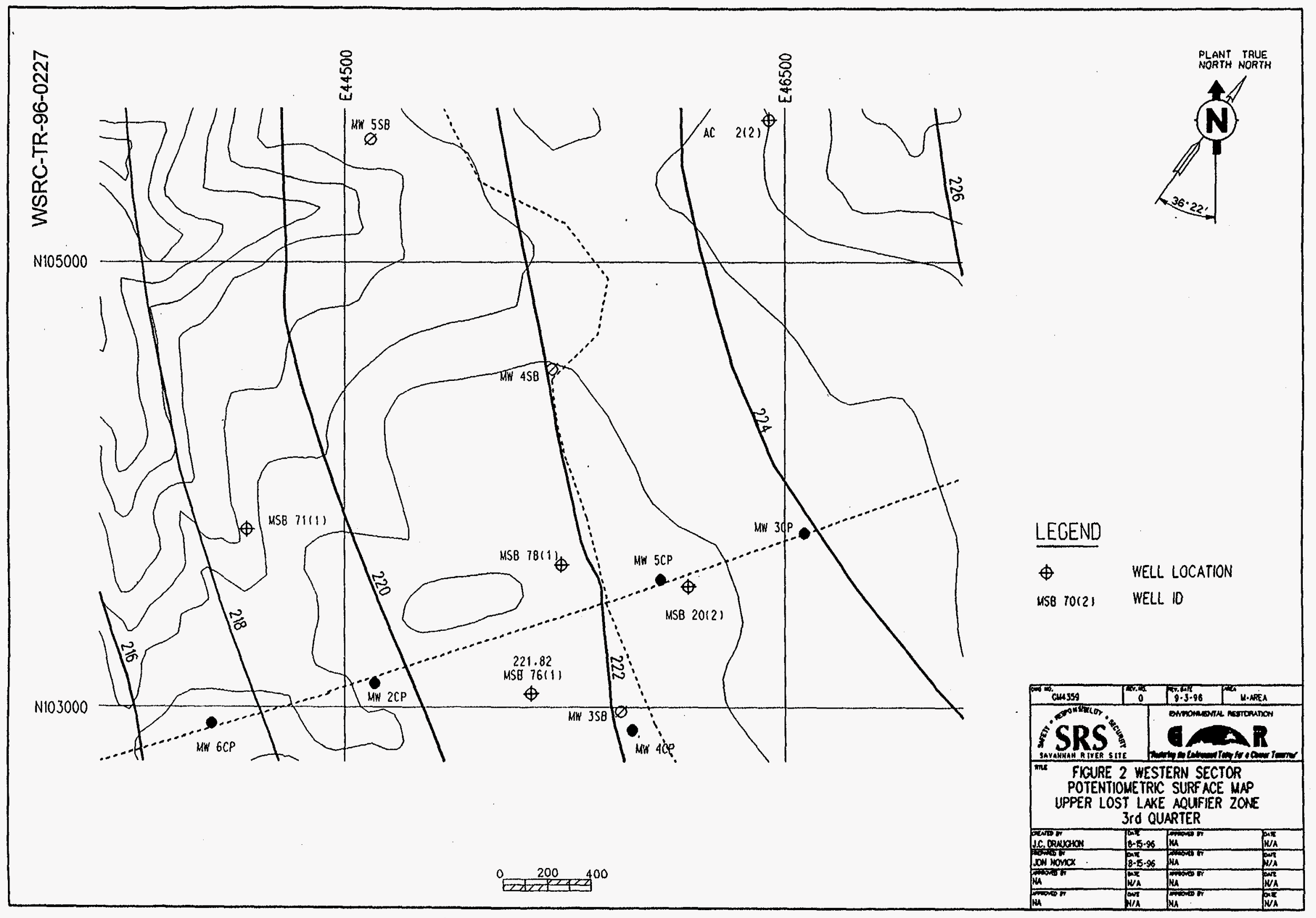




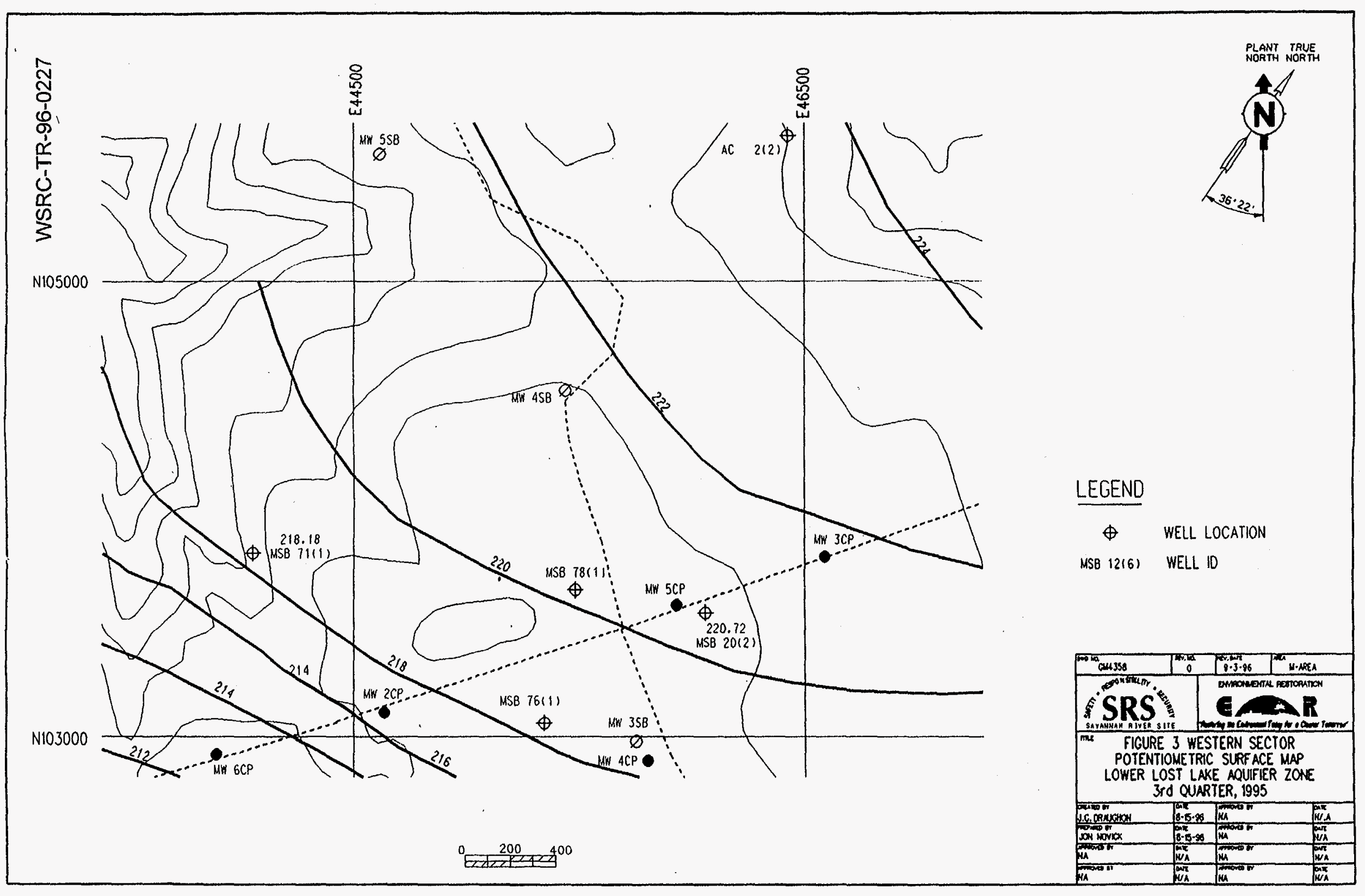




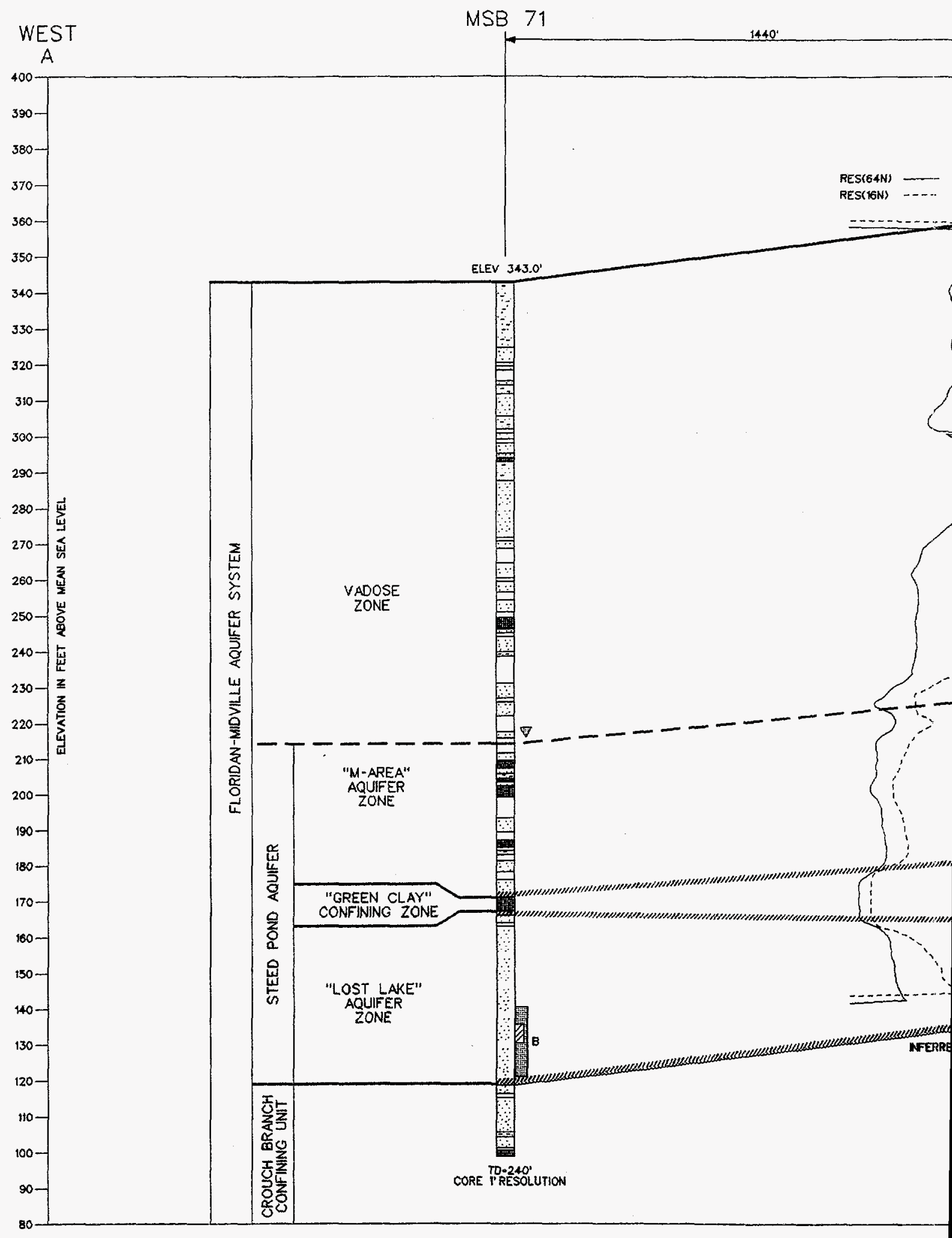

Figure $4 \quad$ Hydrogeologic cross-section near MSB-78B/C 


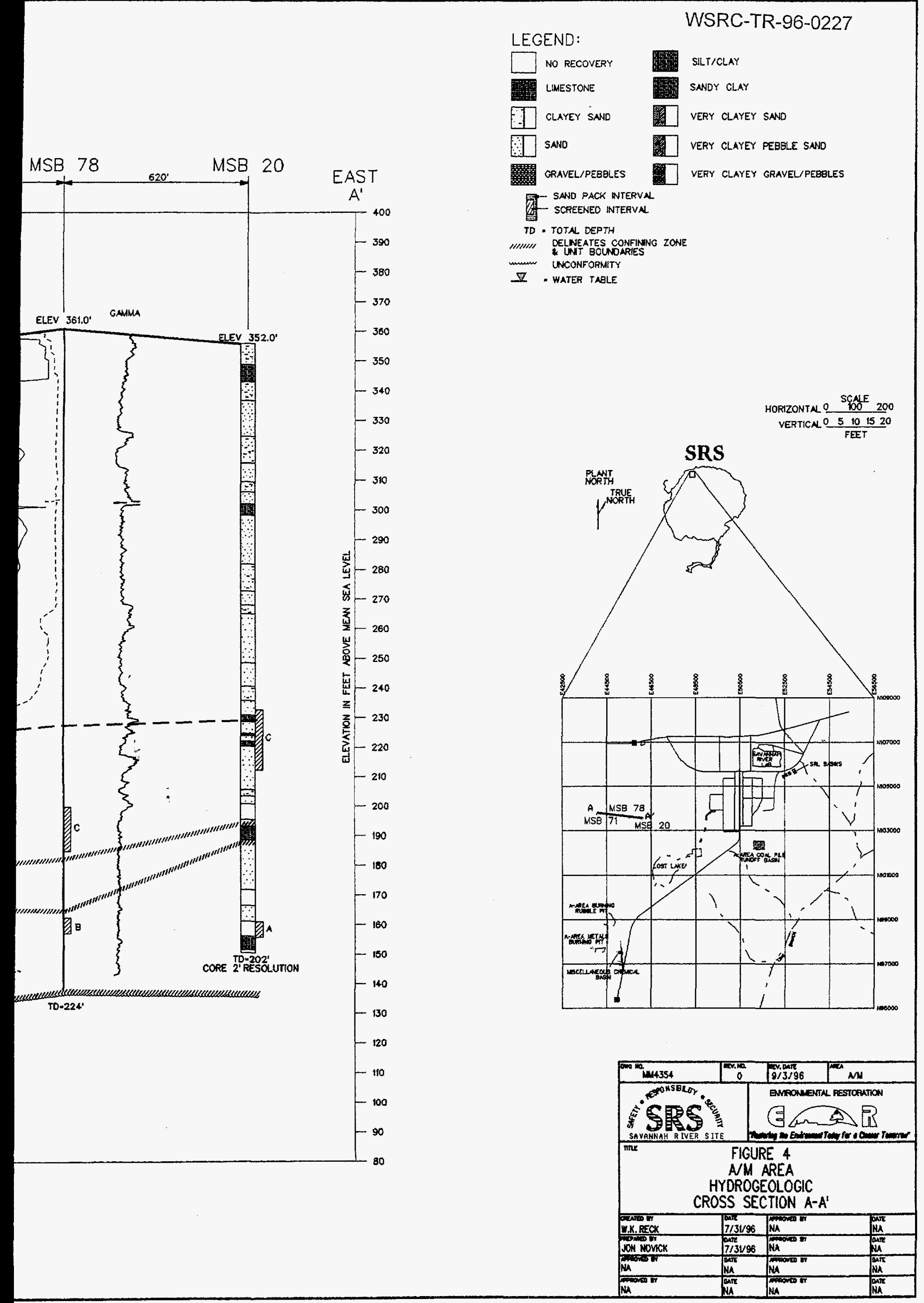


these facilities and is being carried in the direction of groundwater movement. Contaminant plumes exist in the M-Area Aquifer and Lost Lake Aquifer directly beneath the source areas. In areas at some distance from the source area, contamination is primarily concentrated in the Upper and Lower Lost Lake Aquifer Zones and the M-Area Aquifer is not contaminated. This pattern of contaminant distribution is supported by groundwater analysis data from other samples collected at wells located near the MSB-78 well cluster. 


\subsection{WELL INSTALLATION AND CONSTRUCTION DESIGN}

MSB-78B/C was installed in late 1995 in the vicinity of MSB-78D. This well is a temporary well constructed with 2-inch diameter PVC casing and functioned as the pumping well for both aquifer tests conducted at this site in the Upper and Lower Lost Lake Aquifer Zone. MSB-78B/C has dual screen zones, one finished in the upper Lost Lake Aquifer Zone and the other in the lower Lost Lake Aquifer Zone. The upper screen is 17 feet in length while the lower is 15 feet in length, and both are separated by a 15-foot section of casing. This segment of casing is adjacent to a confining unit that separates the upper and lower Lost Lake Aquifer Zones in the vicinity of this well cluster. The screen zones were installed with a filter pack material surrounding the screens, however bentonite was emplaced in the well annulus adjacent to the casing segment that separates the screen zones. Above the upper screen, the annulus is grouted to the surface. $A$ diagram of the construction for MSB-78B/C is illustrated in Appendix A.

Following installation of MSB-78B/C, two other wells, MSB-78CR and $-78 \mathrm{~B}$, were installed close to MSB-78B/C. These wells were constructed according to standard SRS monitor well design standards and will serve permanent monitoring wells at this location. MSB-78CR and -78B are constructed with screen zones 5 -feet in length, and positioned at elevations which correspond to the lower 5 feet of each of the screen zones in MSB-78B/C. As such, MSB-78BR has its screen completed in the Lower Lost Lake Aquifer Zone while MSB-78CR has its screen completed in the Upper Lost Lake Aquifer Zone. These wells were each installed at a distance of 25 feet from $\mathrm{MSB}-78 \mathrm{~B} / \mathrm{C}$ and are constructed of 2-inch PVC casing. This relatively close distance from the pumping well was required because of the low maximum pumping rates that can be achieved from 2-inch diameter wells and the need to observe the slight hydraulic responses to this pumping. 


\subsection{TEST DESIGN, INSTRUMENTATION, AND FIELD TEST METHOD}

\subsection{Site instrumentation}

Once the wells were installed the site was instrumented to conduct the two aquifer tests. MSB$78 \mathrm{~B} / \mathrm{C}$ was utilized as the pumping well for each of the tests while hydraulic responses were monitored in MSB-78BR and -78C. The first test was conducted in the Upper Lost Lake Aquifer Zone by pumping the upper screen zone and monitoring for hydraulic response in MSB-78CR. The second test was conducted in the Lower Lost Lake Aquifer Zone by pumping the lower screen zone and monitoring for response in MSB-78BR. Prior to each test the screen zone to be pumped was isolated from the other screen by placing an inflatable packer in the section of casing between the screen zones. Configuration was relatively simple for the Upper Lost Lake Aquifer Zone test because the pump was situated above the packer. Configuration was more difficult for the Lower Lost Lake Aquifer Zone test because the pump had to be suspended below the packer and pumped water had to pass through a flow-through pipe. Additionally, the electrical wiring had to pass through the packer to operate the pump during this test.

A Grundfos Redi-flo2 pump was utilized to perform the aquifer tests while a Campbell Scientific CR-10 data logger with 4-20mA (full-scale) pressure transducers was utilized to monitor hydraulic responses to pumping in MSB-78BR and -78C. Water level responses were not monitored in the pumping well because the 2-inch well diameter was too small to permit a sensor to be lowered into the well while the pump was in the well. MSB-78CR was equipped with a 5-psi pressure transducer while MSB-78BR was equipped with a 10-psi pressure transducer. Both wells were monitored during each of the tests so that the effectiveness of the packer seal could be verified. Pumping rates were monitored using a factory calibrated totalizing flowmeter. Discharge from the pumping well was fed directly into a tanker truck for transport to a permitted air stripper facility.

\subsection{Test design}

The aquifer tests were limited in terms of pumping rate because of the relatively small well diameter and in pumping duration because of the requirement to containerize and dispose of purged water at a permitted air-stripper facility. Maximum pumping rates that have been achieved in 2-inch wells using Redi-flo2 pumps are in the 7-8 gallons per minute (gpm) range. The maximum achievable pumping duration is equal to the time it takes to fill the tanker truck to its capacity of 2000 gallons. This length of pumping was not required during each test because water levels re-equilibrated before the tanker truck was completely filled up.

The first test was conducted in the Upper Lost Lake Aquifer Zone on June 6, 1996. Pumping was initiated at 0925 and continued until 1430, for a duration of 305 minutes. A total of 1235 gallons were pumped from the Upper Lost Lake Aquifer Zone. Water level monitoring was initiated 25 minutes before the start of pumping and continued for 49 minutes following the cessation of pumping. Measurements were recorded every 30 seconds throughout the pre-test period, pumping period, and post-pumping period. A sample was collected after 4 well volumes were purged at the beginning of the test and a second one was collected approximately 1 minute prior to termination of pumping.

The second test was conducted in the Lower Lost Lake Aquifer Zone on June 12, 1996. Pumping was initiated at 0905 and continued until 1135, for a duration of 150 minutes. A total of 615 gallons were pumped from the Lower Lost Lake Aquifer Zone. Water level monitoring was initiated 12.5 minutes prior to the start of pumping and continued for 1441 minutes following the cessation of pumping. Measurements were recorded every 30 seconds throughout the pre-test period, pumping period, and post-pumping period. A sample was collected after 4 well volumes were purged at the beginning of the test and a second one was collected approximately 1 minute prior to termination of pumping. 


\subsection{ANALYSIS}

\subsection{Drawdown response}

Responses to pumping were analyzed using analytical models developed by Hantush and Jacob (1955). The Hantush model was developed for application in confined aquifer settings where there is significant leakage into the pumped aquifer from adjacent aquifer(s) during aquifer testing.

The field data was developed using a standard Microsoft Excel spreadsheet, including preparation of input files for the analysis program. The analysis was conducted using the software program AQTESOLV Version 2.01, developed by Geraghty and Miller, Inc. Although options exist within AQTESOLV for analysis of recovery data, analysis of field data from this part of the aquifer tests was not conducted because the analytical models do not account for leakage from adjacent formation. The field setting in the vicinity is thought to be a leaky, confined setting therefore the analytical method accounting for leakage is thought to provide results that more accurately reflect the natural conditions.

Data processing did not include a correction for atmospheric pressure variation during the test. Previous analysis has indicated that atmospheric pressure changes over the relatively short time periods during which the tests are conducted (4-5 hours) do not appreciably effect water levels in the wells.

Within AQTESOLV the non-linear least square method was employed as a first-cut in matching the field data with the analytical curve. The initial match was fine-tuned with manual adjustments.

\subsection{Groundwater chemistry}

Groundwater samples were collected during each aquifer test. Two samples were collected during each test, the first one immediately following the purging of four well volumes of groundwater from the well, and the second just prior to cessation of pumping. The four volatile organic samples were analyzed in the SRTC ADS Laboratory by Gas Chromatography - Mass Spectroscopy, using the ADS method 2656. 


\subsection{RESULTS}

\subsection{MSB-78CR Test}

A graph of water level responses to pumping in the Upper Lost Lake Aquifer at MSB-78B/C is illustrated below in Figure 5. Measurements were obtained in monitor well MSB-78CR. The maximum amount of drawdown detected in this well is just under two feet. Drawdown had practically re-equilibrated after 305 minutes of pumping. Water levels immediately began to recover following the termination of pumping, however water levels had not recovered to pre-test levels at the time monitoring was stopped.

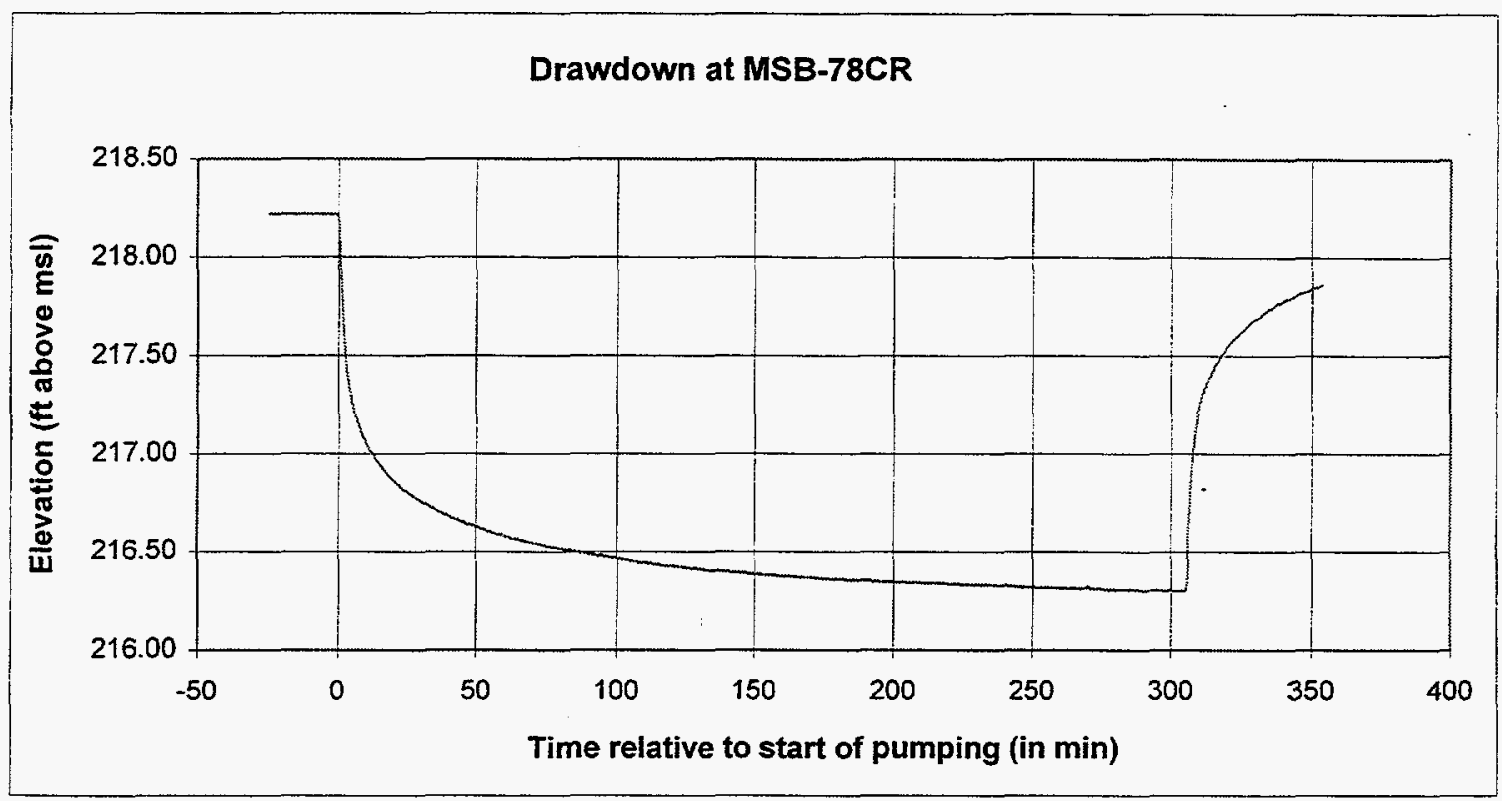

Figure 5

Graph of MSB-78CR water level response to pumping in MSB-78B/C

A graph illustrating the matching of the field drawdown curve, from water level responses monitored in MSB-78CR, with the theoretical Hantush-Jacob type curve is illustrated below in Figure 6. The graph is shown on log-log axes. The deviation of the two curves at times prior to 2 minutes is attributable to the "wellbore storage" effect. The theory assumes that water is extracted from a line source in the center of the well and that the porous media is continuous through the wellbore. This theoretical condition cannot be satisfied and the fact that the initial water purged from the well is produced from storage in the wellbore, and not from aquifer material, has the efffect of causing actual drawdown to be less than theoretical drawdown for a short period of time at the beginning of the test. After two minutes of pumping, the degree of conformance of the field and type curve is extremely close. The calculated values of Transmissivity, Storativity and Leakance $(\mathrm{r} / \mathrm{B})$ are calculated to be $0.13 \mathrm{ft}^{2} / \mathrm{min}$., $5.925 \mathrm{E}-05$, and $3.951 \mathrm{E}-02$, respectively. The pumping rate during this test was steady at $0.55 \mathrm{ft}^{3} . \mathrm{min}$, the radial distance from the pumping well is $25 \mathrm{ft}$. and the borehole and casing radii are $0.667 \mathrm{ft}$. and $0.167 \mathrm{ft}$., respectively. 


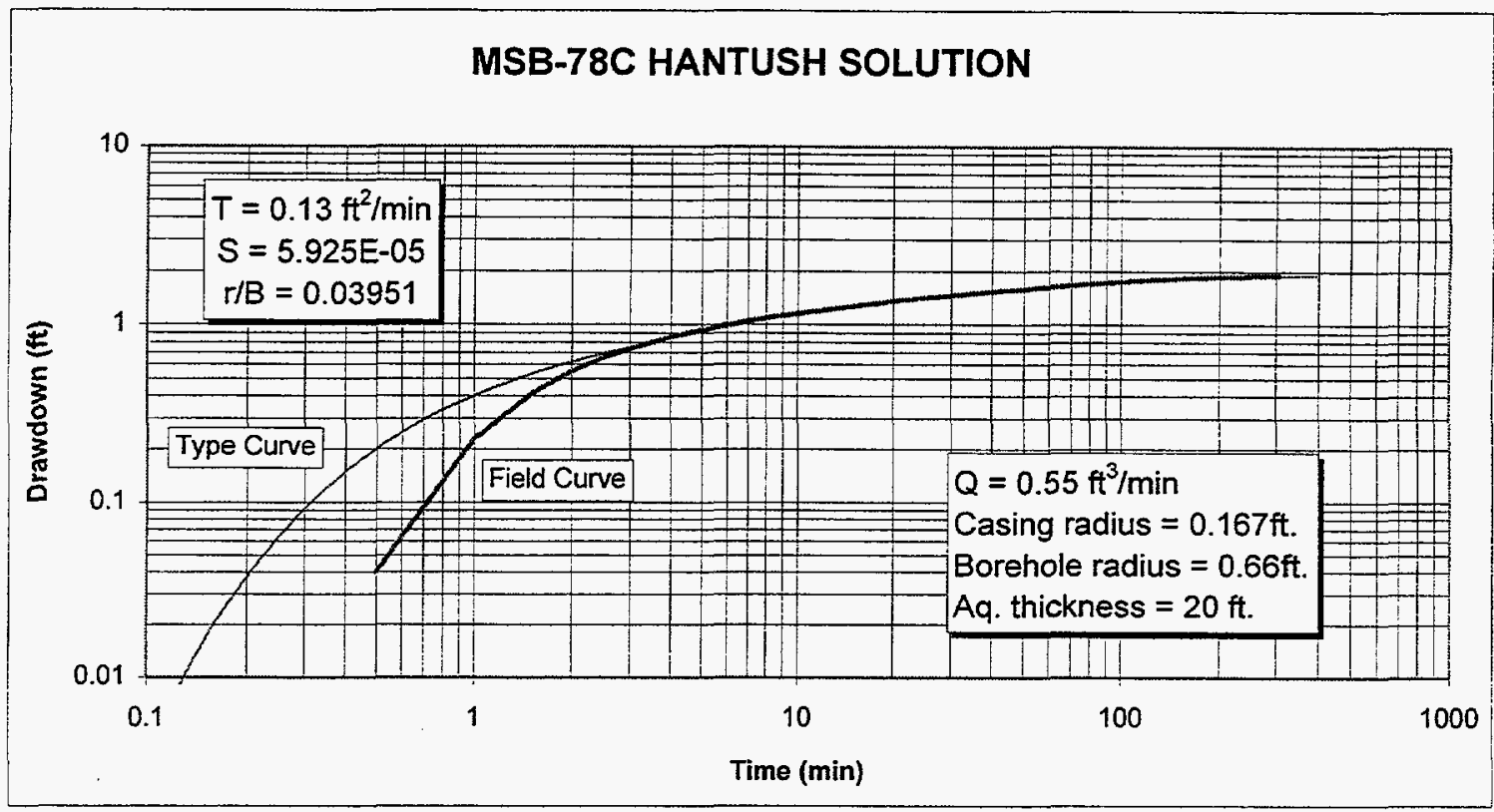

Figure 6

Analysis of drawdown at MSB-78CR.

\subsection{MSB-78BR Test}

A graph of water level responses in MSB-78BR to pumping in the Lower Lost Lake Aquifer at $\mathrm{MSB}-78 \mathrm{~B} / \mathrm{C}$ is illustrated below in Figure 7. Drawdown occurred rapidly following the start of pumping and gradually diminished with time. The maximum amount of drawdown detected in this well is approximately 0.6 feet. Water levels had nearly re-equilibrated after 150 minutes of pumping. Following the termination of pumping water levels experienced a rapid recovery, however a "spike" in water levels is observed immediately after the pump was shut off but dissipated after 5 minutes. The spike is thought to have resulted from the backwashing of water from the pump discharge line after the termination of pumping. There was no check valve on the pump to prevent such an event. After 5 minutes water levels returned to the more typical recovery pattern and reached pre-test levels after 150 minutes. 


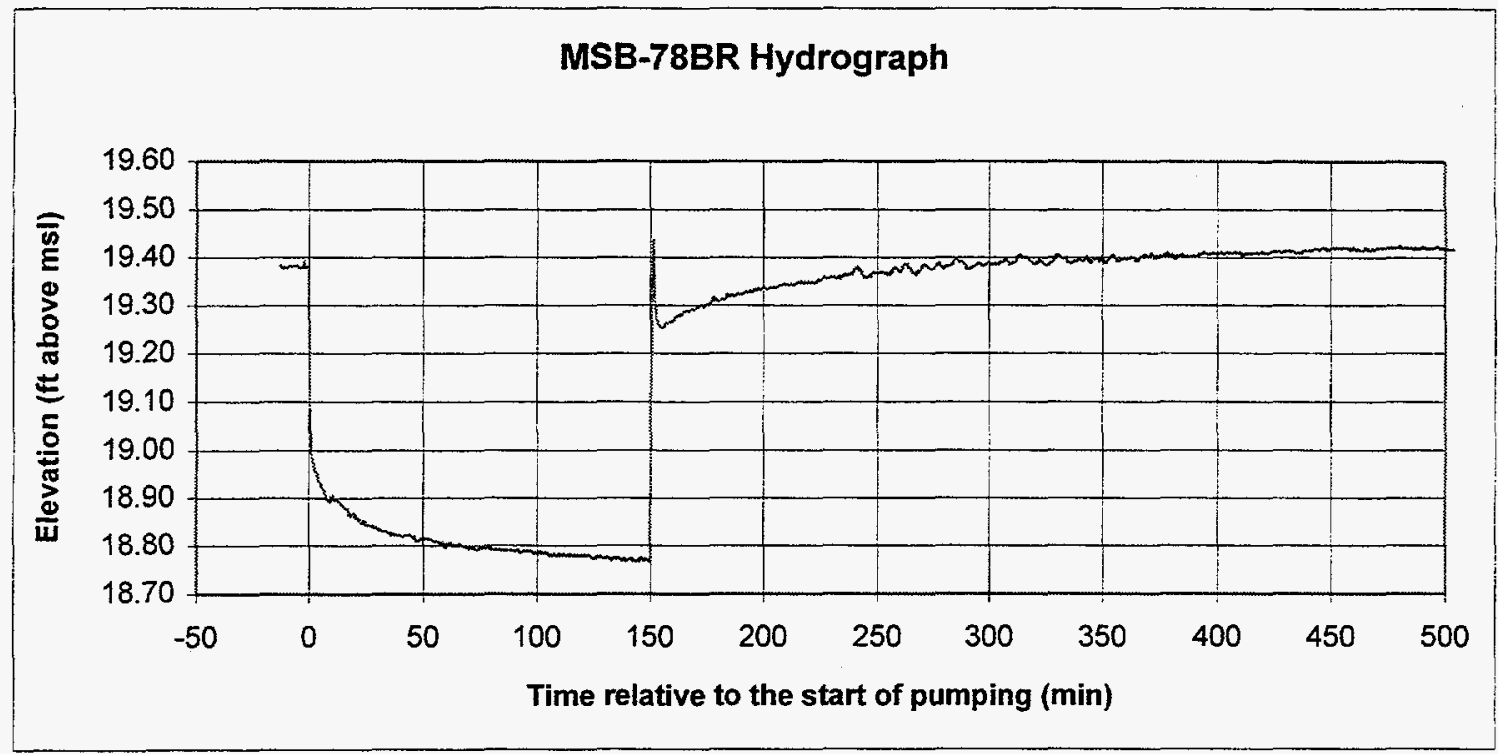

Figure 7

Graph of MSB-78BR water level response to pumping in MSB-78B/C

A graph illustrating the matching of the field drawdown curve, from water level responses monitored in MSB-78CR, with the theoretical Hantush-Jacob type curve is illustrated below in Figure 8. The graph is shown on log-log axes. The calculated values of Transmissivity, Storativity and Leakance $(\mathrm{r} / \mathrm{B})$ are calculated to be $0.752 \mathrm{ft}^{2} / \mathrm{min}$., $3.541 \mathrm{E}-06$, and $3.638 \mathrm{E}-03$, respectively. The pumping rate during this test was steady at $0.55 \mathrm{ft}^{3} / \mathrm{min}$, the radial distance from the pumping well is $25 \mathrm{ft}$. and the borehole and casing radii are $0.667 \mathrm{ft}$. and $0.167 \mathrm{ft}$., respectively.

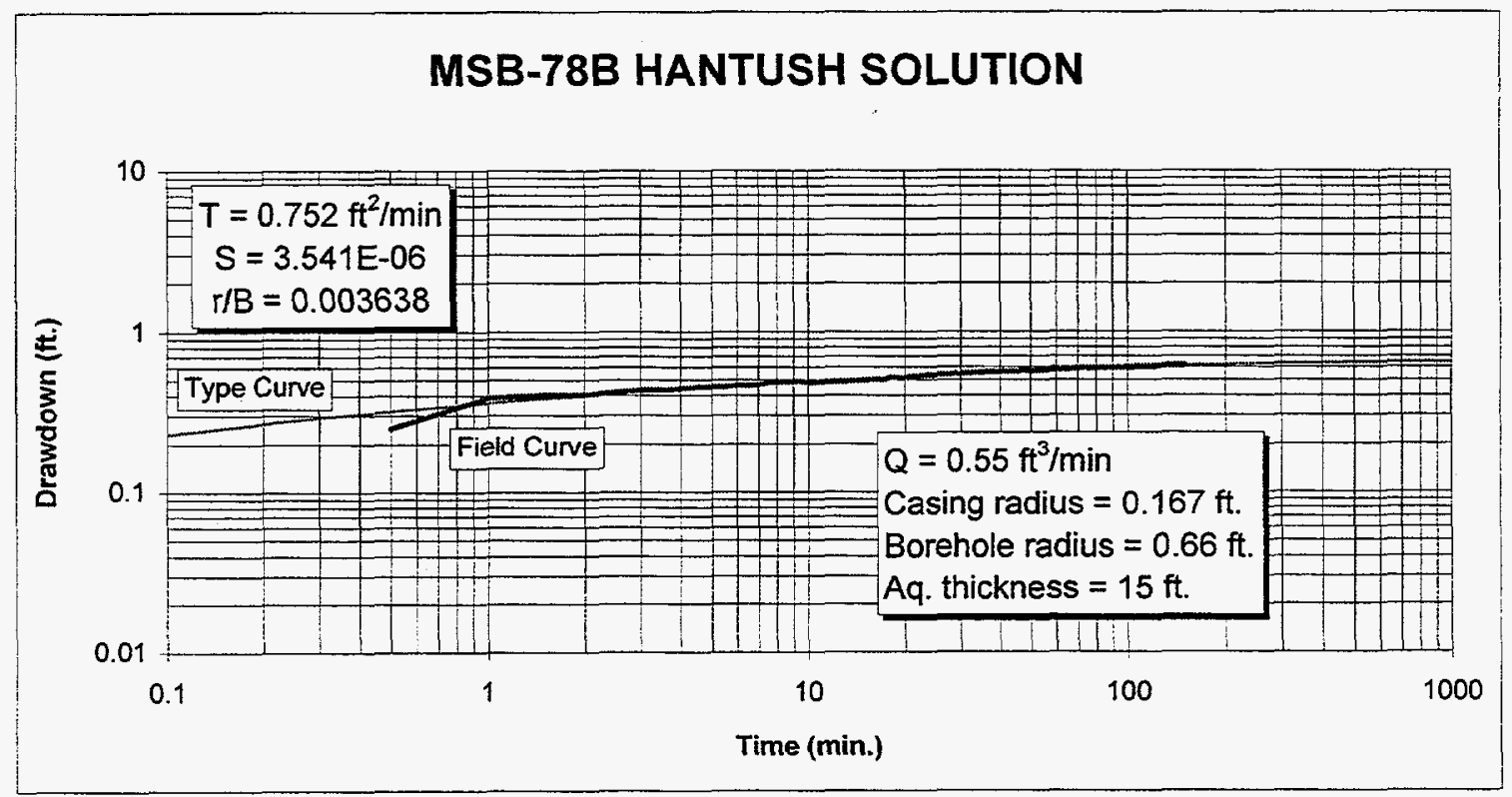

Figure $8 \quad$ Analysis of drawdown at MSB-78BR 
Listed below in Table 1 is a summary of the hydraulic parameters that were acquired from conducting the two aquifer tests.

\begin{tabular}{|c|c|c|c|c|c|c|c|}
\hline WEL & $\left(\mathrm{ft}^{2} \mathrm{~T} / \mathrm{min}\right)$ & $S$ & $\mathrm{r} / \mathrm{B}$ & $\begin{array}{l}b \\
(\mathrm{f})\end{array}$ & $\left(t_{\text {min }}^{\mathrm{K}}\right)$ & (Nday) & $(\mathrm{m} / \mathrm{sec})$ \\
\hline MSB-78BR & 0.752 & $3.54 \mathrm{E}-06$ & $3.64 E-03$ & 15 & $5.01 E-02$ & 72.14 & $2.55 E-04$ \\
\hline MSB-78CR & 0.13 & $5.93 E-05$ & $3.95 \mathrm{E}-02$ & 20 & $6.50 \mathrm{E}-03$ & 9.36 & $3.30 \mathrm{E}-05$ \\
\hline
\end{tabular}

Table $1 \quad$ Summary of hydraulic parameter values for both aquifer tests.

These values are quite similar to the range of values estimated from previously conducted multiple-well tests at higher pumping rate, or longer-duration tests conducted in the Upper and Lower Lost Lake Aquifer Zones at other locations within the A/M Area. For reference, a table of values for hydraulic parameters from other aquifer tests conducted in the Lost Lake Aquifer somewhere in the AM area is presented below in Table 3. Tests conducted at these wells were the so called "multiple-well tests" which are thought to provide more reliable estimates of hydraulic parameters than single-well or slug tests.

\begin{tabular}{|c|c|c|c|c|c|c|}
\hline WEL & Aquiffer Unit & $\left(\mathrm{f}^{2} / \mathrm{min}\right)$ & $\mathrm{S}$ & I/B & (ft) & $\mathrm{K}(\mathrm{ftm})$ \\
\hline MSB-32B & LLLAZ & 1.6535 & $2.5 E-04$ & 0.0262 & 32 & $5.17 \mathrm{E}-02$ \\
\hline MSB-32C & ULLAZ & 0.8804 & $1.8 \mathrm{E}-04$ & 0.0312 & 14 & $6.29 E-02$ \\
\hline MSB-78BR & LLLAZ & 0.752 & $3.54 \mathrm{E}-06$ & 0.0036 & 15 & $5.01 \mathrm{E}-02$ \\
\hline MSB-78CR & ULLAZ & 0.13 & 5.93E-05 & 0.0395 & 20 & $6.5 \mathrm{E}-03$ \\
\hline MSB-67C & LLLAZ & 0.6355 & $8.02 \mathrm{E}-05$ & 0.4317 & 20 & $3.18 \mathrm{E}-02$ \\
\hline MSB-68C & LLLAZ & 1.127 & $1.68 \mathrm{E}-04$ & 0.1043 & 20 & $5.64 \mathrm{E}-02$ \\
\hline MSB-47B & LLLAZ & 0.7833 & 7.39E-05 & 0.2187 & 20 & $3.92 E-02$ \\
\hline
\end{tabular}

Sources of information: Hiergesell and Pemberton (1995); Hiergesell (1994)

Note: $L L A Z=$ Lower Lost Lake Aquifer Zone, ULLAZ = Upper Lost Lake Aquifer Zone

Table 2 Comparison of hydraulic parameters calculated in this investigation with other estimates for the same aquifer zones in AM Area.

\subsection{Confining unit vertical hydraulic conductivity}

The values of $r / B$ can be used to calculate an "averaged" value for vertical hydraulic conductivity, $K_{v}\left(\right.$ or $K^{\prime}$ ), for the low permeability unit separating the two aquifer zones. An assumption must be made that all of the leakage is derived through either the overlying or underlying confining unit to use this approach. Estimates are made using the formula:

$$
\begin{aligned}
B=\left(T b^{\prime} / K^{\prime}\right)^{1 / 2} \text { where: } & B=\text { leakage factor }[L] \\
& T=\text { transmissivity of aquifer zone }[L]^{2} /[t] \\
& b^{\prime}=\text { thickness of the confining zone }[L] \\
& K^{\prime}=\text { vertical hydraulic conductivity of confining zone }[L] /[t]
\end{aligned}
$$

Rearranging the terms of the equation:

$K^{\prime}=\mathrm{Tb}^{\prime} / \mathrm{B}^{2}$ 
For the data obtained from the Lower Lost Lake Aquifer Zone and using a radial distance of $25 \mathrm{ft}$, the distance from the monitor well to the pumping well, the following estimate of $K^{\prime}$ was calculated.

$$
\begin{aligned}
K^{\prime} & =\left(0.752 \mathrm{ft}^{2} / \mathrm{min}\right) \times(15 \mathrm{ft}) /(6868 \mathrm{ft})^{2} \\
& =2.4 \mathrm{E}-07 \mathrm{ft} / \mathrm{min} \\
& =3.44 \mathrm{E}-04 \mathrm{ft} / \text { day }
\end{aligned}
$$

This value of vertical hydraulic conductivity of the confining unit is in the upper range for permeability of an unweathered clay.

For the data obtained from the Upper Lost Lake Aquifer Zone and using a radial distance of $25 \mathrm{ft}$, the distance from the monitor well to the pumping well, the following estimate of $\mathrm{K}^{\prime}$ was calculated.

$$
\begin{aligned}
K^{\prime} & =\left(0.13 \mathrm{ft}^{2} / \mathrm{min}\right) \times(15 \mathrm{ft}) /(633 \mathrm{ft})^{2} \\
& =4.87 \mathrm{E}-06 \mathrm{ft} / \min \\
& =7.01 \mathrm{E}-03 \mathrm{ft} / \text { day }
\end{aligned}
$$

This value of vertical hydraulic conductivity of the confining unit is slightly higher than the range for permeability of an unweathered marine clay.

\begin{tabular}{|c|c|c|c|c|}
\hline \multicolumn{5}{|c|}{ MSB 78BR AQUIFER TEST SAMPLES } \\
\hline SAMPLEID & DATE. & TIME & $\begin{array}{c}\text { TCECONC } \\
\text { (ughl) }\end{array}$ & $\begin{array}{c}\text { PCE CONC } \\
\text { (ught) }\end{array}$ \\
\hline MSB-78B/C-1B & $6 / 5 / 96$ & 0935 & 69 & $<10$ \\
\hline MSB-78B/C-2B & $6 / 5 / 96$ & 1429 & 64 & $<10$ \\
\hline \multicolumn{5}{|c|}{ MSB $78 C$ R AQUIFER TEST SAMPLES } \\
\hline SAMPLESB & DATE & TIME & $\begin{array}{c}\text { TCE CONC } \\
(u g / l)\end{array}$ & $\begin{array}{l}\text { PCE CONC } \\
\text { (ug/L) }\end{array}$ \\
\hline MSB-78B/C-1C & $6 / 12 / 96$ & 0915 & $84+1-6$ & $<10$ \\
\hline MSB-78B/C-2C & $6 / 12 / 96$ & 1134 & $64+1-4$ & $<10$ \\
\hline
\end{tabular}

\subsection{Chemical analyses of groundwater samples}

Analyses of groundwater samples collected during the aquifer tests indicate that TCE is present in both the Upper and Lower Lost Lake Aquifer Zones in concentrations that range from 64 to 84 ug/L. These concentrations range from 10 times to 15 times the primary drinking water standard (PDWS). Table 3, shown below, summarizes these values.

Table 3 Results of groundwater sample analyses

The nearest monitoring wells to the MSB-78 cluster also indicate the presence of TCE in the subsurface. The MSB-76 well cluster is located approximately 600 feet east of MSB-78 and the TCE concentration in the Upper Lost Lake Aquifer is relatively high, ranging from 12 to $15 \mathrm{mg} / \mathrm{L}$ in samples collected during the past few years. No analysis for TCE in the Lower Lost Lake well was found in the geochemistry data base for the Lower Lost Lake well at the MSB-76 cluster. The next closest cluster is the MSB-20 cluster and TCE concentrations are below the PDWS in the Upper Lost Lake Aquifer Zone, ranging from 1 to 2 ug/L. Concentrations in MSB-20A well, a horizon deeper than the Lower Lost Lake Aquifer Zone, are reported as ranging from 785 to $1030 \mathrm{ug} / \mathrm{L}$ during the 1994-1995 time period. 


\subsection{CONCLUSIONS}

The hydraulic parameter estimates obtained in this investigation suggest that satisfactory results were obtained from the two multiple-well aquifer tests conducted by pumping each screen zone in $\mathrm{MSB}-78 \mathrm{~B} / \mathrm{C}$. Evidence to support this is includes the high degree of correspondence between field data curves and the analytical curves, as seen in Figures 6 and 8 . Values of hydraulic conductivity calculated in this investigation were 6.5E-03 ft/min and 5.01E-02 ft/min for the Upper and Lower Lost Lake Aquifer Zones, respectively. These values are quite similar to the range of values estimated from previously conducted multiple-well tests at higher pumping rate, or longer-duration tests conducted in the Upper and Lower Lost Lake Aquifer Zones at other locations within the AMM Area (see Table 2). Multiple-well tests are thought to provide more reliable estimates of hydraulic parameters than single-well or slug tests.

The feasibility of using a 2-inch diameter well with dual screen zones as the pumping well for separate aquifer tests of the zones adjacent to each of the screens was demonstrated in this investigation. With the use of an inflatable packer each screen zone was successfully isolated from the other when it was pumped. Evidence of this is demonstrated by the fact that no discernible response to pumping was detected in MSB-78CR (ULLAZ) when the lower screen zone (LLLAZ) was pumped in MSB-78B/C. Likewise, when the upper screen zone (ULLAZ) was pumped, no discernible response was detected in MSB-78BR (LLLAZ). Because of space constraints inside a 2 " diameter well, it was not possible to monitor water levels within MSB-78B/C when it was pumping.

The main advantage of using a multiple screen well as the pumping well for separate tests in each screen zone is that the installation costs of a single well is less than for installation of separate wells to conduct each of the tests. Although there may be an additional cost for packers the overall cost is significantly less with the use of a single well. A well of such construction can easily be installed in the vicinity of existing well clusters to conduct multiple-well tests at each monitored horizon. Wells that are installed with fully penetrating screen zones are not well suited for ongoing groundwater quality monitoring and are frequently abandoned after an aquifer test is conducted. Considering that pumping wells are likely to be a temporary items, it would seem prudent to minimize the number of wells that will be abandoned following the tests.

Care must be taken in instrumenting each site so that credible estimates of parameters may be obtained. Wells must be located at appropriate distances from one another and be constructed with screen zones of the appropriate length and at the appropriate elevations. If possible, pumping well screens that fully penetrate the aquifer zone should be installed so that the most straightforward analytical methods can be used to calculate hydraulic parameters. This consideration is especially important if observation wells are located close to the pumping well, as is usually the case when 2 -inch wells are used to conduct aquifer tests. The critical distance is usually taken to be a distance equal to twice the aquifer thickness. 


\subsection{REFERENCES}

Aadland, R. K., J. A. Gellici, and P. A. Thayer, 1995, Hydrogeologic Framework of West Central South Carolina, South Carolina Department of Natural Resources, Water Research Division, Report 5.

Hiergesell, R.A., and Pemberton, B.E., 1995. Final Report: Aquifer testing with 2-Inch diameter wells in the A/M Area Southern Sector. WSRC-TR-95-0365, Westinghouse Savannah River Company, Aiken, SC.

Hiergesell, R.A. 1994. Hydrologic analysis of data from the Lower Lost Lake Aquifer at Recovery well RWM-12 (U), WSRC-TR-93-666, Westinghouse Savannah River Company, Aiken, SC.

Looney, B.B., and Jones, W.E., 1992. Assessing DNAPL Contamination, AMM Area, SRS: Phase I Results (U). WSRC-RP-92-1302, Westinghouse Savannah River Company, Aiken, SC. 


\section{APPENDIX}


LLING SUBCONTRACTOR ALLIANCE ILLER T-Hornsby

te of Well installation $3 / 26 / 96$

ZH. O.S.ICO. NAME WSRC/BHtiogesell, B. VanPelt

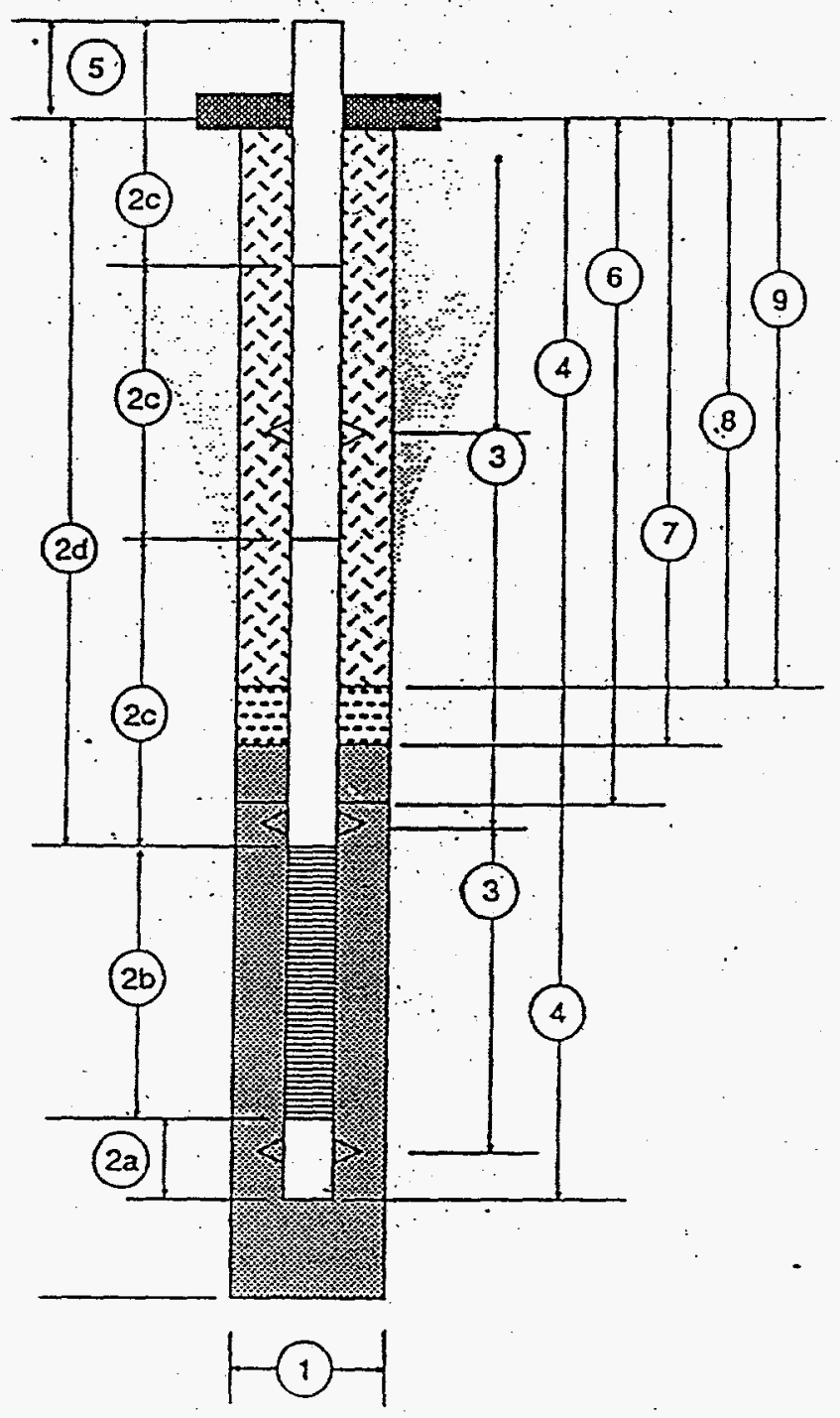

WELL NUMBER MSB-78BR

SRS COORDINATES

SANITARY SĖAL ELEVATION

NOTE: ALL MEASUREMENTS

ARE FFOM GROUND

SURFACE AT START

OF BORING - MEASUREMENTS

TO NEAREST 0.1 FOOT.

1) Total Drilled Depth/Hole Diameter

$220 / 77 / 8$

2) Casing/Screen Tally (M̈easured to Nearést 0.01 Foot)

(a) Sump \& Plug Longth 5.

(b) Sereen Length 5

(c) Casing Joint Longths (Measured in Uphole Sequenos From Top of Screen). $10,10,1 \mathrm{Ci}, 10$, $10,10,10,10,10,10,10,10,10,10 ;$ $10,10,10,10,10,10,10,1.5$

(d) Depth to Top of Screen 209

3) Depths to Centralizers $2213.5,173.5,133.5,93.5$ $53.5,13.5$

4) Total Depth of Installod Well 219

5) Casing Stick Up (Standard 2.5 A.G.S.) Z 2.5

6) Depth to Top of Fitter Pack _ 207

7) Depth to Top of Fine Sand Seal _ 204.7

8) Depth to Top of Bentonite Seal 195.5

9) Thickness of Grout _ 195.5 
WSRC-TR-96-0227

DRILLING SUBCONTRACTOR EMTC DROLER_ Erick Fleming

DATE OF WELL INSTALLATION 12/11/95

TECH. O.SJCO. NAME Wavne Parker/SAIC

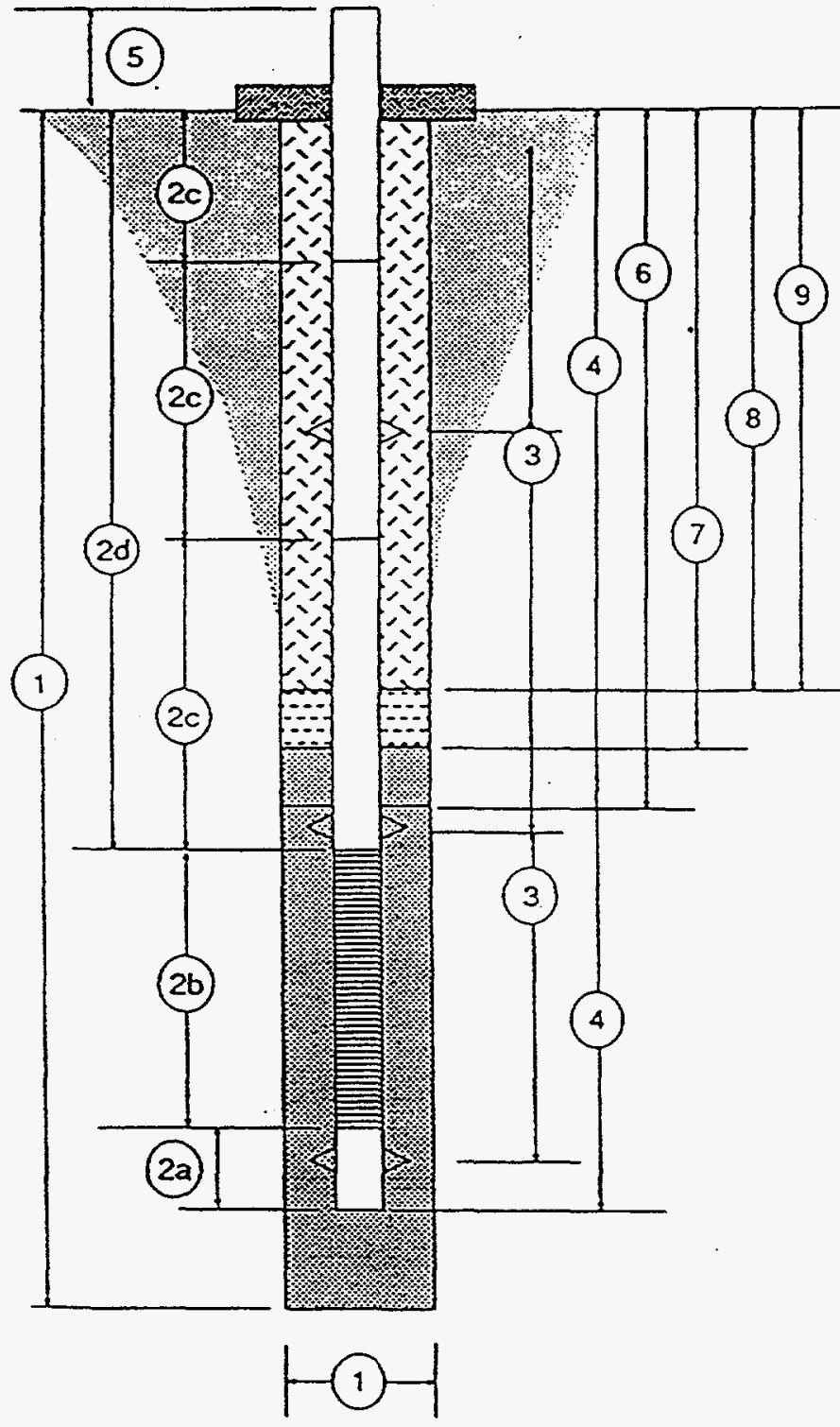

*Preliminary: Pad/protective casing not yet installed.
WELL NUMBER MSB 78 C/B

SRS COORDINATES N103649.32

E45991.73

SANITARY SEAL ELEVATION 361.76*

NOTE: ALL MEASUREMENTS

ARE FROM GROUND

SURFACE AT START

OF BORING - MEASUREMENTS

TO NEAREST 0.1 FOOT

1) Total Drilled Depth/Hole Diameter__224/7-7/8"-in

2) Casing/Screen Tally (Measured to Nearest 0.01 Foot)

(a) Sump \& Plug Length

$2.49+0.34=2.83$

(b) Screen Length

17.5 - Ton: 15.02 - bottom

(c) Casing Joint Lengths (Measured in Up-hole Sequence from Top of Screen)

$9.98,999,998.998,9.98,100$

$10.0,10.0,10.0 .9 .99,9.99,10.0$

$10.0,10.00,10.0$

(d) Depth to Top of Screen

$166.5 / 199.03$

3) Depths to Centralizers

$125,85,45,165,215$

4) Total Depth of Installed Well

216.88

5) Casing Stick Up (Standard 2.5' A.G.S.) 3.37

6) Depth to Top of Filter Pack Lower Screen: 198.8 Upper Screen: 162.4

7) Depth to Top of Fine Sand Seal None Used

8) Depth to Top of Bentonite Seal

Screen: 1847 Upper Screen: 157.3

9) Thickness of Grout

157.3 
"LING SUBCONTRACTOR AlliANCE DRILLER I. Hornsby JATE OF WELL INSTALLATION ECH. O.S.ICO.NAME WSRC/B.VanPert, B. Hiergesedl

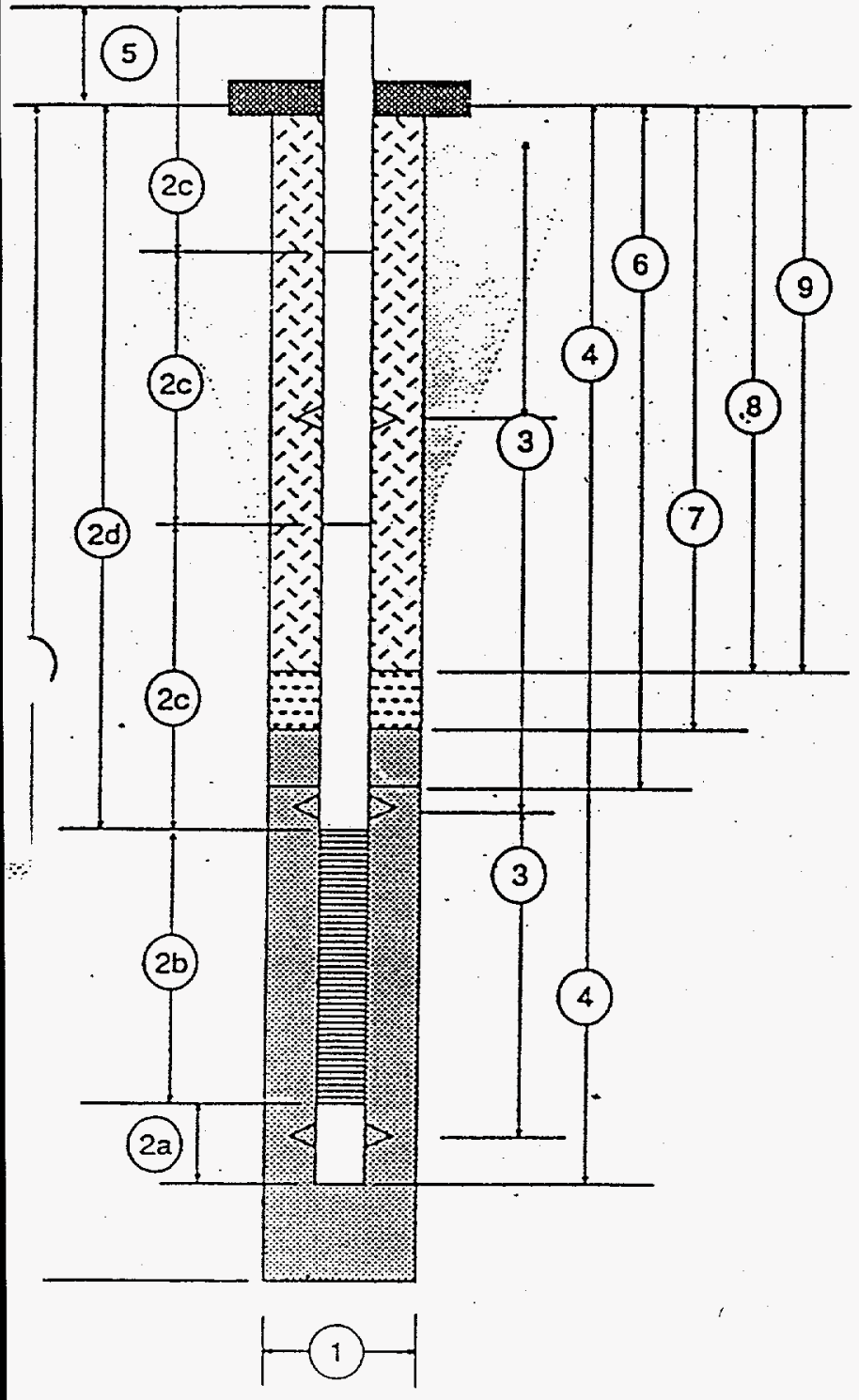

WELL NUMBER MSB-78CR SRS COOROINATES

SANITARY SEALL ELEVATION

NOTE: ALL MEASUREMENTS

ARE FROM GROUND

SURFACE AT START

OF BORING - MEASUREMENTS

TO NEAREST 0.1 FOOT.

1) Total Drilled Depth/Hole Diameter $190 / 77 / 8^{\prime \prime}$

2) Casing/Screen Tally (Measured to Nearést 0.01 Foot)

(a) Sump \& Plug Length $\quad 5^{i}$

(b) Screen Length $5^{i}$

(c) Casing Joint Lengths (Measured in Uphole Sequence From Top of Sereen) $10.0,10.4510 .0$, $10.0,10.0,10.0,10.0,10.0,10.0,10.0 ;$ $10.0,10.0,10.0,10.0,10.0,10.0$ $10,0,10,0 ; 2.5$

(d) Depth to Top of Screen $180^{\prime}$

3) Depths to Centralizers $188^{\prime}+78^{\prime}, 138^{\prime}, 98^{\prime}, 58^{\prime}, 18^{\prime}$

4) Total Depth of Installed Well 190

5) Casing Stick Up (Standard 2.5' A.G.S.) 2. 2.5

6) Depth to Top of Fiter Pack 177

7) Depth to Top of Fine Sand Seal 175:7

8) Depth to Top of Bentonite Seal __ 1625

9) Thickness of Grout _ 165 